\title{
THE RESULTS OF REFORM
}

In reading an essay by Mr. Augustine Birrell on Sir Robert Peel, I felt something of a jar on coming upon a reference to Peel as an anti-reformer. Peel's achievements were just such as in the United States would have secured his reputation as a great reformer. He carried Catholic Emancipation, resumed specie payments, established the gold standard, repealed the corn laws and initiated the policy of free trade. "No statesman of the century," says $\mathrm{Mr}$. Birrell, "has left his mark so plainly inscribed upon both the statute book and the life and business of the nation as Sir Robert Peel," and then Mr. Birrell proceeds to class among anti-reformers this statesman whose whole career is associated with radical measures of legislation which caused new party alignments and greatly altered the complexion of English politics. Canning, a statesman of the same order, who raised the issue of Catholic Emancipation, which Peel took up and successfully concluded, is referred to as "a fierce anti-reformer," while Peel's attitude is described as one of "opposition to reform" although not with the expectation of resisting it, but rather of acting as a brake upon the movement. Although the explanation instantly occurred that the reference here was to a specific measure of parliamentary reform, yet the characterization of such a statesman as an anti-reformer grated like a false note.

Assuredly no suggestion of reproach was intended, as would be the case in this country were the term applied to an American politician. In England, it appears that there is still no sense of incompatibility between active solicitude for good government and opposition to reform, whereas in this country, to say that a public man is solicitous for good government is taken as implying that he is a reformer, while on the other hand opposition to reform implies callous partisanship or habitual subserviency to sordid motives.

This difference of usage has frequently struck me in my reading, and when I came upon it in Mr. Birrell's essay, I had the curiosity to pursue the significance of the word through other political writings by British authors. Instances were found in which reference was made to reform in the general sense of amendment, but when used specifically the word invariably designated reform in parliamentary representation. A series of great measures, such as in the 
United States would go by such designations as Election Reform, Ballot Reform, Social Reform, etc., were not put in the category of reform. The competitive examination system which we imported from England under the name of civil service reform does not figure much in English political literature, for it appears never to have had attributed to it in that country the high constitutional importance attached to it in this, but if it is mentioned one will find it under the head of "competitive examinations" and it is treated simply as a detail of administration.

The distinction between English and American usage in this particular is comparatively recent. Reform is not a word that figured to any extent in the vocabulary of the Fathers, -indeed it hardly belongs to the literature of their period,--but we find instead an occasional use of the word "reformation," applied in a general sense to the correction of public morals. Thus Jefferson speaks of "points of legislation prominent in character and principle, urgent, and indicative of the general pulse of reformation." The Federalist, written to advocate a radical reform of government, has little or nothing to say about "reform." The fifteenth number contains an energetic statement of the wretched condition of public affairs, which if written in our times would have been a commentary on the theme "reform is necessary," but the word finds no place in the discussion. It is rarely used in Benton's "Thirty Years' View," although covering a period of almost revolutionary change in the character of the government, nor do we find it in the ordinary vocabulary of editorial discussion of affairs in the Jacksonian period. William Leggett, who edited the New York Evening Post in the thirties, was a vehement censor of defects of government and a vigorous advocate of radical changes in legislative policy and administrative method, but he never advocated reform as such. The word appears to have entered into current usage in the United States as an echo of the long battle over parliamentary reform in England, and while in that country the specific idea of giving a new shape to parliamentary representation adhered to the word, in this country the idea that the political and social institutions of a people could be made to order was attached to it, and reform became the designation of innumerable projects of change ranging from dress and diet to the constitution of society and the organization of government. In New England in the forties reform became an [222] 
epidemical frenzy, quaint details of which are preserved in Emerson's lecture on the New England reformers and in the Brook Farm chapter of Higginson's "Life of Margaret Fuller." Many of the early New England varieties of reform have died out, but Hawthorne's pithy description of the people who regard themselves as important objects of destiny whereas they are simply bores of the first water, remains as the characterization of a type which is always with us. Existing varieties of reform are much more numerous than is generally supposed. An "Encyclopedia of Reform" has been published in a stout volume about the usual size of a drug store pharmacopia. Dealers in literary supplies have lists of reform topics on which they can furnish regular service of matter. You pay your money and you take your choice.

The difference between the English and the American usage of the word reform lies in the fact that in England the word has never quite lost its original signification of to form again or anew, whereas in this country it has become synonymous with improvement. The latter signification is also in frequent use in England, especially among those whose ideas of political improvement involve schemes of organic change (the class of agitators who in Leigh Hunt's time were called radicals are nowadays reformers), but in ordinary usage the word reform does not in England necessarily imply improvement; that is an open question. In the United States the word begs the question of improvement, and the only open question is the best mode of accomplishing reform. The completeness of the identification of reform with improvement, as well as the vast scope given to the concept are well exhibited in the following definition of civil service reform contributed by the late Dorman B. Eaton to the "Cyclopedia of Political Science": "In its general and most comprehensive sense, civil service reform means the removal of abuses in the public service-federal, state and municipal-and the enforcement therein of such just and sound principles and methods as will most contribute to good administration."

A consequence of this identification of reform with improvement is the habit of organic change which is the most marked characteristic of our politics, and to which processes of degeneration are distinctly traceable. That reform may be pernicious sounds to the average American reader like a contradiction in terms, and any argument to that effect has to combat a settled tendency of thought. 
If the concept of the state as an organisn were accepted as scientific doctrine it would be easy to make out the case by logical deduction. If the state is an organism then there is an adaptation between every part and the whole and hence reform anywhere must disturb the balance of all the functions of the organism. This was the argument by which Montaigne resisted constitutional innovation: "Forasmuch as government is a structure composed of divers parts and members joined and united together, with so strict connection that it is impossible to stir so much as one brick or stone, but the whole body will be sensible of it." With such an attitude of thought it would be possible to secure some consideration of the risk that structural reform, even if applied to corrupt tissues, might react dangerously upon the general health just as the suppression of an eruption might produce constitutional disease. But the concept of the state as an organism is not accepted. Contrary to the general tendency of scientific thought as regards all other aggregates having a corporate life, the present drift of political speculation is away from the concept of the state as an organism. True, that concept underlies the political philosophy of Burke whose works have obtained secure rank as a political classic, but Rousseau and not Burke is the architectonic influence in American politics, and it is the fashion to regard the state as an organization effected through the operation of opinion and consent, and subject to rearrangement at will in accordance with the dictates of opinion.

Refraining therefore from any attempt to reach conclusions by deduction, let us look at the facts of the case and scrutinize dispassionately the actual results of reform. At the outset the stubborn fact confronts us that those of our political institutions which work most badly are those which have been reformed the most. Indeed it may be said that the satisfactoriness of our political institutions is in inverse order to the frequency with which they have been subjected to reform. The national government which has been least reformed works with superior vigor and efficiency in every part of administration; our state governments which every now and then are fitted out with the newest fashions of reform, come a long way behind in quality of administration and municipal government which is always being reformed as the perpetual subject of malediction and despair. Moreover this divergence is plainly marked as the accompaniment of reform. The national 
government was originally the chief object of the efforts of reformers. As early as Monroe's adninistration schemes for reforming the Constitution of the United States were prosecuted with great zeal and industry, particularly as regards the mode of electing the president, but by fortunate accident due to the federal composition of our republic, the process of textual amendment is so arduous that the Constitution of the United States is secure against formal change. State constitutions and municipal charters are however exposed in a way that has made them the continual prey of reformers. Those forms of government have been made over and over again, but the more they have been reformed the greater has become the degeneracy of state and municipal government, and the more marked has become the contrast between the quality of administration they produce and that produced by the unreformed Constitution of the United States. A favorite excuse of the reformers, for the failure of their schemes to produce the results expected, exactly parallels the logic of the tailor who contended that the coat he had made was a good coat but the boy was too small. It is argued that popular character has declined under the influence of something or other ("commercialism" is just now the stock phrase), so that good political institutions lose their fitness and that the only thing to do is to develop a proper stature of citizenship. This preposterous mode of reasoning is a staple article of reform literature and is being continually presented with perfect gravity and in all seriousness. It is sufficient for the present purpose to call attention to the fact that this same popular character which is found inadequate by the reformers, underlies the national government, all social institutions and all business activities, as completely as it does state and municipal government, and if that character can accomplish satisfactory results in national administration or in private enterprise it is quite as able to do so in state or municipal government under proper conditions.

The goodness or badness of political institutions is relative. Political values are determinable only by the rule laid down in the Federalist, No. 68, that "the true test of a good government is its aptitude and tendency to produce a good administration." Tried by this test does any one pretend that constitutional reform has been beneficial? On the contrary the corrupt condition of state politics and-in a still greater degree-of municipal politics, is the constant 
theme of reformers, and is indeed the principal argument by which they recommend the adoption of their reforms. In political as in physical disease people do not readily comprehend that it is not the disease which we have to cure but the patient, and that the symptoms are not what we have to deal with but the cause of the symptoms, which may be, and generally is, remote from the parts in which its effects are made visible. The usual practice of reformers in dealing with political disease is to try to get rid of it by suppressing its symptoms or by excising the organ which suffers from it most, reasoning like the man in the street who thinks he would not be troubled with biliousness if he could get rid of his liver. Hence it is difficult to reason with reformers and they listen with impatience and even resentment to any criticism upon their projects that goes beyond questions of detail in mode of application. The mental process by which they elude argument is something like this : "Here is a manifest evil and as good and true men we must do something to cure it. All human effort is fallible and there is room for hostile critics to find fault and pick flaws, yet the measure we are advocating is the best we can think of and is offered with sincere motives, so we think that it ought to be adopted, and hence we are forced to conclude that the opposition we are encountering proceeds from interested and base motives." A man may advise a friend against indiscreet use of colchicum without incurring suspicion of being a friend and an ally of the gout, but to criticise nostrums offered as "ballot reform" or "civil service reform," etc., is almost certain to cause reformers to regard one as a corruptionist or as a "spoilsman." Only in politics do educated people admit of medical treatment based simply upon good intention and a desire to do something. In physical disease of obscure nature merely expectant treatment is a settled rule of procedure, and the main reliance is not upon positive intervention but upon the curative efforts of the organism. All history, our own history in particular, shows that a like policy is the only safe one in political disease, and that while reform nostrums produce fresh complications of malady, real improvement comes from the gradual operation of hygienic activities in the political organism.

A striking example of this is presented in the contrast between national and state administration to which I have already adverted. Reform attacked the national government before it did the state [226] 
goveruments, and there was plenty of justification for it according to the mode of reasoning practiced by reformers. What is known as the democratic movement was the result of social transformations imparting to the body politic a more sensitive nervous organization and a more widely diffused consciousness. The people were aroused into political activity and became desirous of obtaining a more active participation in the conduct of government than was provided for in the original constitutional scheme. They then became aware of what appeared to be abuses urgently requiring reform. At that time the suffrage in the states was narrowly limited; and the state legislatures appointed presidential electors as they pleased, elected United States Senators as they pleased and provided for the election of state quotas in the House of Representatives as they pleased. Gross inequality of political circumstances prevailed and it seemed as if sweeping constitutional reforms would be required to secure the people in the rights they demanded. No wiser spirit dominated the national reform movement than that which has had such pernicious results in state and municipal reform, but owing to the immobility of the federal constitution the movement to secure popular election of the presiclent by formal amendment of the constitution failed completely, and yet the same end has been so completely accomplished by processes of constitutional development that the mass of the people now do not even know that there was a time when they had no vote as to who should be president, and when a small portion of the people of a state could elect the whole of the members of the House of Representatives from that state as a solid delegation. The whole character of the government has been popularized, and the presidency has been converted into a representative institution, without any reform whatever in political structure.

The degeneracy of state and municipal politics dates from this very reform movement happily defeated in national politics. The waves of impulse which beat in vain upon the impregnable constitutional barriers of the federal union went roaring over the state constitutions. Then began the multiplication of elective offices which dissipate public responsibility and destroy popular control in state and municipal politics. The people can control the national government because every administrative office is comprehended in a system of responsible appointment at the head of which stands 
the president whom the people elect. The people cannot control local government because responsibility has been reformed out of them, and the offices are filled under a system of irresponsible appointment administered in the name of the people by the politicians for the interest of the politicians. The only thing that makes the results of reform at all tolerable is that the interests of the politicians cannot be wholly severed from the general interests of the community, but nevertheless the loss and injury are enormous. It does not matter what party elects the president or who he may be; the people know perfectly well that he will appoint treasurers and controllers who will take good care of the public funds; but under the system of elective treasurers and controllers provided by the reformed state constitutions the custody of the public funds is systematized as an agency of political corruption and individual profit, and, in addition to the regular squeeze constantly going on, heavy defalcations sometimes occur. The national government has no advantage in the material upon which it has to draw; the same class of men who engineer local politics also officer the local agencies of the national government. When democratic conditions of administration were first established, there was little difference in tone between national and state administration and malfeasance was as common in the one as in the other, but the comparative immunity of the national administration from reform, giving it stability and continuity, has enabled a gradual adaptation to the needs and responsibilities of public service to take place, and details of management have been perfected so that fecleral office holders find themselves under conditions which produce a different and much higher grade of service than they can render under the conditions of state administration. The difference is so distinctly marked that it receives general recognition, and the public feels a confidence in the integrity of officers of national administration which is not extended to officers sustaining analogous functions in state administration. No one expects that the fiduciary conduct of the clerk of a state court, or of a county treasurer, shall be as scrupulous as that of the clerk of a United States conrt or of a subtreasurer of the United States, and the difference would be expected to appear in the behavior of the same individual transferred from a state to a federal office of like duties. In this case it is plain that the whole difference consists of difference in conditions, and that 
this difference in conditions must be the result of reforms to which state and municipal administrations have been subjected.

The national administration itself furnishes a conspicuous illustration of the distinction between improvement and reform. Considered as an improvement in administration the system known as civil service reform has strong arguments in its favor, but its advocacy as an improvement implies conformity to existing conditions and adaptation to beneficial ends. This attitude was carefully maintained during the introduction of the system in Great Britain. The measures taken were tentative and care was taken to keep in touch with public opinion as reflected in the disposition of parliament. Mr. Eaton in his work on "Civil Service in Great Britain" remarks: "Wise methods steadily and faithfully applied, which educate public opinion at the same time that they close the fountains of mischief, and not sweeping, revolutionary proceedings, which assume that the moral tone of a nation's politics can be changed by an assault or an exhortation, were in the opinion of the British public, the essential conditions of all administrative reform." Mr. Eaton was fond of the word reform and used it as a synonym for improvement. What was in England carefully restricted to the sphere of improvement was in this country converted into a reform which speedily became an end in itself so that "sweeping, revolutionary proceedings" were not objectionable. Hence we have had a great deal of civil service reform with so little improvement that the sessions of civil service reformers are consumed by lamentations over the evil tendencies of the times. As is the habit of reformers, although they admit the evil sequences, they are unwilling to regard those sequences as results, and the only remedy they have to offer is stronger and bigger doses of reform. Nevertheless the fact is incontestable that the period following the imposition of civil service reform upon American politics by executive fiat exhibits an exacerbation of all the maladies for which civil service reform was prescribed. Even the most hardy civil service reformer will not contend that following the act of 1883 and its rapid development by executive orders, there was any increase of moderation, order, judgnient and control in the management of public affairs. On the contrary there was a marked increase of passion and recklessness in our politics. If we look simply to the one matter of financial economy we find that during the ascendancy of civil service reform, 
from 1883 to 1898 , the ordinary expenses of administration increased 140 per cent, while the population increased 37 per cent. Since I898 comparisons are vitiated by expenses of the Spanish War and the cost of its ensuing responsibilities, but there is no satisfactory evidence of any direct improvement due to civil service reform, unless the means be taken for the end and the extension of civil service reform be regarded as an improvement irrespective of its consequences. At the same time we have the admission of reformers that state and municipal governments abound with evils and abuses, and yet in many places in this field civil service reform has received even more extensive application than in the national administration and rests upon a firmer basis since it is embodied in constitutional requirements and statute law, whereas in the national government it is still almost wholly dependent upon executive regulations which may be altered or rescinded at the will of the executive. The local extension of civil service reform is not however accompanied by any perceptible improvement in the tone of government, while its trammels upon executive discretion and responsibility are such that it is becoming a question whether with the best will in the world good government is possible under civil service reform regulations as they now exist. This is the problem with which Mayor Low of New York is wrestling.

The history of other reforms might be cited to show that reform by no means implies improvement but rather the contrary. What is known as ballot reform would afford a typical instance of the evils of reform did space permit of a detailed discussion. The common experience of citizenship may however be appealed to in proof of the assertion that ballot reform has inflicted upon the people so cumbrous and perplexing a mode of voting that when elections are close it is a matter of great doubt whether the result as declared corresponds with the intention of a majority of the voters. The Australian system upon which it is based is a precise and simple method of ascertaining the will of the people, but converted into a reform nostrum and in jected with American politics, it has produced the most complicated system in the world. The records of all ages and in all countries might be challenged to produce the equal of such a grotesque monstrosity as the American blanket ballot. The present tendencies of ballot reform now constitute the greatest danger of American politics. As it is the characteristic disposition 
of reformers to force conditions to suit their institutions instead of following nature's method of suiting institutions to conditions, the predilection of the people in favor of casting a group vote for a party ticket has inspired a strong desire to abolish party organization so far as possible by providing for nominations by direct vote. This effort to grind citizenship into what Burke described as "the dust and powder of individuality" will, so far as it can succeed, set up dire processes of political degeneracy. Human nature is so constituted that to reduce citizenship to an inorganic mass acting by units instead of corporately is impossible, but what may be done is to substitute for the agency and control of responsible party management the casual incitements of demagoguery and the transient cohesions of mob impulse. There are already localities in which the direct vote system of nominations prevails where it is almost impossible to secure the election of a decent man for office, since nominations are practically confined to the class of politicians denoted as good "mixers,"-those who can stomach the job of a personal canvass, hobnobbing with "the boys" and standing treat in the saloons. I know of a city whose politics have been so corrupted and debased by the direct vote system that a mayor who handled public funds with such jolly recklessness as to land him in prison, subsequently secured a re-election through a party nomination obtained by direct vote, after a canvass of energetic hospitality upon the candid platform "give a man a chance to show that he can do right."

The teachings of our own experience as to the evils of reform are borne out by history in general. Our reformers are fond of referring to the superiority of municipal administration abroad as an incentive to efforts toward betterment in this country, but the superiorities they admire are not due to reform but to an immunity from reform which has permitted the gradual adaptation of institutions to the needs of the community. When the Rev. Dr. John P. Durbin, president of Dickinson College, published his "Observations in Europe" made during a tour begun in 1842 , he combatted English aspersions upon the working of American institutions by pointing to the disgraceful squalor and neglect of English municipal government. He mentioned that "of the $5^{86}$ streets of Leeds, sixty-eight only are paved by the town; the remainder are either paved by owners, or partly paved, or are totally unpaved, with the surface 
broken in every direction, and ashes and filth of every description accumulated upon many of them." Similar or worse accounts were given of the quality of municipal administration in Manchester, Glasgow, Newcastle, Liverpool and Hull. These very cities are mentioned by Albert Shaw in his work on "Municipal Government in Great Britain" as models of municipal administration and their excellences are set forth as inspiration and example to American municipal reformers. All this immense improvement has been accomplished without any reform of the frame of municipal government. The Municipal Corporations Act of I 835 , under which such vast progress has been accomplished, was in existence when Dr. Durbin made his observations, and under its provisions the model municipalities Dr. Shaw describes have been developed and are still administered. In I 882 another general Municipal Corporations Act was passed, but it was a codification of existing laws, and as Dr. Shaw remarks, "the chief outlines of the act of 1835 remained unobscured." Dr. Shaw, although himself a municipal reformer, pointed out in a paper read at the sessions of the National Municipal League in 1899 that "in the United States we have been making and unmaking municipal charters, and meanwhile administering them as badly as possible, while in Europe they have been bending their energies to the work of administering progressively and well such charters as their cities found provided for them in the general statutes."

The beneficial results of immunity from reform are to be seen not alone in British municipal government but in the entire aspect of the British constitution. It is a commonplace of English history that political development has been carried on without alteration of the historic framework of the constitution, and popular government has been established and is carried on under the same constitutional forms that sheltered despotic monarchical rule in past ages. Furthermore, philosophic historians show that this functional development has been made possible by the fact that the anatomy of the state was too solidly established to be radically changed, fixity of type facilitating continuity of functional development. But if reformers could have had their way this development would have been arrested. The early phases of the parliamentary type of government were denounced and resisted as corruptions by the reformers of the eighteenth century, and projects for tinkering the consti- 
tution into some sort of mechanical excellence according to the ideas of the times were as abundant then as now. There was a copious output of reform literature in which one may find the same propensity for political experimentation, the same confidence in legislative nostrums, and the same inculcation of acceptance of them as a moral duty, which characterize American reform literature to-day: Burke had these reform tendencies in view when, referring to the English constitution, he wrote: "Never will I cut it in pieces, and put it into the kettle of any magician, in order to boil it in the puddle of their compounds into youth and vigor; on the contrary I will drive away such pretenders." The reformers railed at Burke's conservatism, and scouted his proposals of improvement without reform as trivial and inadequate, but the reformers were never strong enough in England to control legislation and frustrate the gradual course of improvement by which alone real progress is effected. The defeat of the eighteenth century reformers in England left the way open for the successful establishment of the control of public opinion over the agencies of government, through the formation of the cabinet system.

It is interesting to note however that the methods of administration produced in England by natural growth and functional development without organic change, lose their salutary character when they are adopted as a reform nostrum to be injected into the government of other countries. Historians are now agreed that had Prussia submitted to the demands of the reformers who would have imposed upon that country the English type of parliamentary government, the establishment of the German Empire in all human probability could not have taken place. Indications are multiplying to the effect that parliamentary institutions are a melancholy failure on the continent of Europe, and the contrast between the rising power of Germany and the decadence of Austria, Italy and Spain is traceable to the obstinate resistance of the rulers of Prussia and their ministers to the adoption of parliamentary government as a reform, although gradually accepting its procedure to as great an extent as was approved by considerations of practical convenience.

Those who have studied most deeply the operations of destiny in the affairs of nations arrive at the same conclusion no matter what tract of history they explore. "An appetite for organic change is the most dangerous disease which can affect a nation," 
says Lecky. "The nations which devote themselves to social reform are lost nations," declares Renan. Akin to such views is Bagehot's remark that in great governing races there is always a certain amount of stupidity, which simply means that there is in the national character a conservatism of habit which resists plausible seductions of reform and insures the natural growth of institutions from the roots of race motive and experience. Looking at the great changes in the map of the world from age to age we find that the future has belonged not to the clever, self-conscious, cultured peoples but to the stubborn, the practical, the tenacious, whose institutions are an organic growth. Not the quickwitted Greeks but the dull, steady Romans became masters of the civilized world. "Rome was the strongest power in the world before any analysis of its government was attempted," remarks Professor Dunning in his recent work on the history of poitical theory. Not the brilliant, versatile, intelligent Poles, but the plodding Prussians and the stolid Russians developed the great powers of modern Europe, one nation beginning as a little province subordinate to Poland and the other as barbarian tribes on the eastern confines of the vast Polish commonwealth. Institutions which endure can not be made to order by the cleverest intelligence, but must grow instinctively from the character and circumstances of the people. The vital parts of every stable form of government may be traced back to the usages of barbarians, founded upon instinct and habit, while no philosophic scheme of government has ever been a success.

It may be asked whether we must then accept the melancholy paradox that man, although his possession of reason is his proud distinction among the animal tribes of nature, cannot trust that faculty for political guidance, but is better off in dependence upon the instinctive cohesions arising from his social nature. Certain it is that instinct is generally the safer guide. Even in states which have developed political consciousness and some power of giving rational determination to their conduct, the fundamental activities of their political life consist of instinctive habits of thought and action, acquired from race discipline and operating almost unconsciously. In this respect there is a complete analogy between political organism and physical organism, the fundamental activities in each being automatic and not controlled by conscious volition. As with intelligent beings so with political organism, there is a sphere 
for rational determination of conduct, and it is the province of political science to guide the exercise of reason in affairs of state. But the fact is that we have as yet no comprehensive system of political science to act as the support of statesnuanship. Certain branches of ethics, economics and jurisprudence are classified under the head of political science, but apart from these branches, so-called political science is a mere float of conjecture taking transitory shape from the sentiments and ideas of the times. Professor Sheldon Amos in his "Science of Politics" admits that there is no such science in the sense of universal principles permanent in their applicability, and that the predicates of political science as regards the state must be regarded as applying only to "that integral unity which has been discovered by the accidents of European development." The purport of this is simply that there are no scientific standards of political judgment but what passes for such are impressions received from "accidents of development." Every age has accepted the political ideal evolved from its past as the ultimate type, the preservation of which appears as the proper object of political effort. Hence no age has ever correctly interpreted its own tendencies. The initial phases of new developments are apt to appear as corruption of the old order. To Aristotle and Plato the decaying city-state was the norm of political organization and the perfection of that type was the object of their political speculations. To Polybius and Cicero the diverse structure arising from the vicissitudes of Roman development was taken as the model of polity at the very time when it was breaking down, and then was first produced the check and balance theory of government which is still extant. During the middle ages traditions of the Roman empire controlled the ideas of jurists and reformers. To Dante and Petrarch the rise of nationality was a hideous phenomenon indicating a baleful process of disintegration repugnant to Holy Writ and portending the decay of civilization. In the fourteenth century when Sir John Mandeville was on his travels all he could see in the formative processes of modern Europe going on around him was evidence of a sad state of spiritual decay, and he mourns that "pride, covetousness and envy have so inflamed the hearts of worldly lords that they are busier to disinherit their neighbors than to claim or conquer their right heritage," the Holy Land. The builders of states are always denounced by the moralists of their times. Melancholy as the state- 
ment may seem yet it is a truth attested by all history that if in any age the character of political institutions had been decided by the moral sentiment then in vogue, that which later ages have accepted as a providential order would have been perverted. Political theory always lags behind political conditions, and constitutional systems become justified only after they have been accepted as a necessity and conformed to in practice.

The inherent danger of reform therefore appears to lie in the fact that it operates by deduction from some traditional theory instead of by practical induction from actual conditions. The theory may have been at one time a useful fiction like the classic theory of checks and balances in government which the Whigs of the eighteenth century adopted as a cover for the transfer of authority from the crown to the cabinet, but whatever may be the possibilities of political science when scholarship achieves something worthy of the name, as yet political theory does not possess sufficient solidity to serve as a basis for statesmanship. It is hardly more than a vapor arising from streams of sentiment, and the reformer builds for disaster because he designs his architecture with regard to the contour of this cloudland. His schemes are evolved in view of an ideal civitas so completely non-existent outside of his own fancy that one wonders how some earnestly advocated reforms can survive so much experience of actuality as a ride in a street car or a walk along the highway.

If these considerations seem to suggest mere quietism or apathy as the better part, that is simply a fresh illustration of the predisposition to regard reform as identical with improvement. There need be no abatement of effort because reform is discredited, but on the contrary political activity will gain in definiteness and certainty of purpose by cutting loose from theory and moving upon the plane of practical redress of specific grievances. Doubtless there are reform projects from which valuable suggestions of practical advantage may be obtained, but such a habit of distrust for anything offered in the name of reform as will compel convincing proof that it is an improvement will be in every way wholesome. Substantial improvement of state and municipal government is hardly possible without radical legislation cutting away the complex entanglements produced by the past activities of reformers, but this can best be accomplished as an incident of party activity actuated by party 
needs in seeking to accomplish concrete results demanded by public sentiment. By this I do not mean to imply that party activity is necessarily curative in its constitutional operation. On the contrary, when degeneracy sets in, party activity tends to spread and deepen the process. If our republic, like the Roman republic, were involved in all its tissues by the disintegration of constitutional authority, the same result would ensue: sloughing of the diseased structure and decline of its functions. If the national government had been involved by the process of organic change to which states and municipalities have been subjected, constitutional government would long since have broken down from sheer incapacity and Casarism would have been produced by pressure of social necessities. As it is, national party activity whose nature impels it to co-ordinate all political function in connection with national authority, contains a principle of regeneration strong enough to reach and influence local politics, and there are reasons for believing that it will eventually bring them into gradual conformity to the type which our national politics will evolve. A process of this kind is in operation but it would gain immensely in vigor by a strong popular reaction against reform. There are indications that such a reaction is coming. In the revival of party enthusiasm and the concentration of thought and effort upon party ends speculative politics will fall into wholesome neglect and reformers will find their occupation gone.

HenRy Jones Ford.

Pittsburg. 